Vrzhyzhevskyi E. L. ${ }^{1}$, Taranova T. G. ${ }^{1}$, Akhonin S. V. ${ }^{1}$, Yavdoshchyna E. F. ${ }^{1}$, Solomiychuk T. G. ${ }^{1}$, Zvorykin C. O. ${ }^{2}$

${ }^{1}$ E. O. Paton Electric Welding Institute of NAS of Ukraine. Ukraine, Kiev

${ }^{2}$ Ukrainian Research Institute of Aviation Technology, JSC. Ukraine, Kiev

\author{
PECULIARITIES OF LONG-TERM STRENGTH \\ OF WELDED JOINTS OF HEAT-RESISTANT TITAN ALLOYS \\ AFTER LOCAL THERMAL TREATMENT DURING EBW
}

For development of new competitive aircraft engines it is necessary to use new light heat-resistant titan alloys. It permits to solve the problem of temperature increase in gas-turbine aircraft engine (low-pressure and high-pressure chambers). Specificity of newest alloys utilization requires from them heat-resistance and high ductility availability. The main characteristic of heat-resistance is long-term strength and creep limit. In the present article the tests for long-term strength of titan alloy samples of the following composition (mass \%): Al-9\%: $\mathrm{Sn}-5 \% ; \mathrm{Nb}-6 \% ; \mathrm{Zr}-6,5 \% ; \mathrm{Mo}-5,7 \% ; \mathrm{V}-1 \% ; \mathrm{Si}-0,2 \%$, were carried out in the test laboratory of the E. O. Paton Electric Welding Institute NASU (accreditation certificate No. 2 H362 of January, 14, 2014). Metallographic and fractographic investigations of welded joint samples and basic metal, heatresistant titan alloy investigated. The used method of electron beam welding with local thermal treatment demonstrated the total absence of any defects in welded joints. [dx.doi.org/10.29010/084.9]

Ключевые слова: heat-resistant titan alloys; long-term strength; electron beam welding; structure; micro-hardness.

Introduction

Major problem of reliability increase for aircraft and gas-turbine engines is prevention the risk of breakage of most critical constructional elements [1]. Toughening of requirements regarding operability of critical purposes welded constructions on base of titan alloys may be satisfied by high quality of welded joints.

Actual direction of the investigation is rising of mechanical properties of welded joint up to the level not less than main material properties by prevention of macro- and micro-cracks, as well as porosity in welded joint and seam nearby zone.

\section{Problem statement}

For development of new competitive aircraft engines it is necessary to use new light heat-resistant titan alloys. It permits to solve the problem of temperature increase in gas-turbine aircraft engine (low-pressure and high-pressure chambers). Specificity of newest alloys utilization requires from them high heatresistance and high ductility presence.

In Fig. 1 the scheme of utilization of heat-resistant titan alloys in aircraft engine is presented. Most interest attracts the heat-resistant titan alloys which are characterized with high strength, high specific strength and long-term strength at high temperature.

About possibility of titan alloys to operate at increased temperatures it may be decided, first of all, by temperature dependence of short-term strength properties. Nevertheless, short-term strength could not to be a quantitative characteristic of heat-resistance, because mechanical properties of metals and alloys depend considerably on deformation rate and load action time. The main characteristics of heatresistance are long-term strength and creep limit.

Long-term strength is a maximum strength (strength limit) under which action the material at given temperature is disrupt after prescribed time interval. Creep limit is characterized by maximum strength under which action a material at given tem-

(C) Vrzhyzhevskyi E. L., Taranova T. G., Akhonin S. V., Yavdoshchyna E. F., Solomiychuk T. G., Zvorykin C. O., 2018 


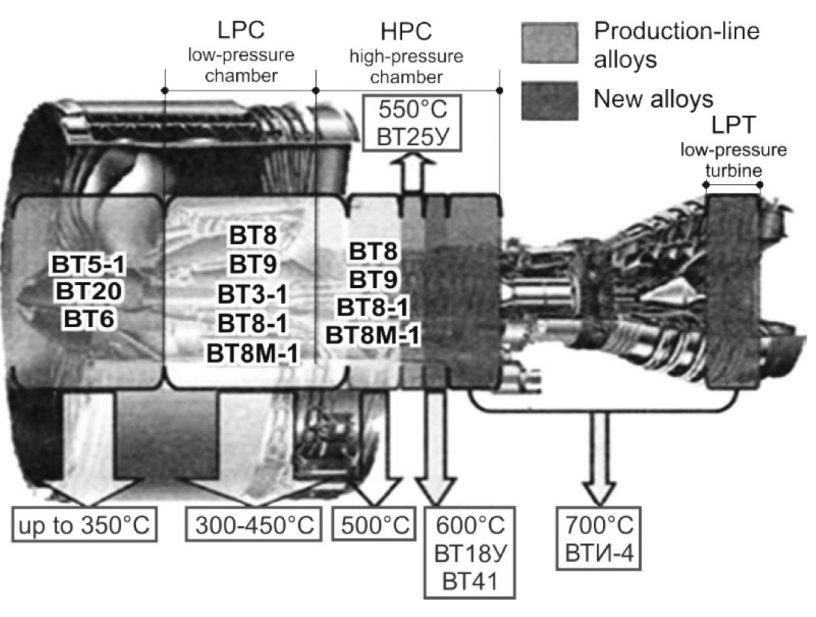

Fig. 1. Utilization of heat-resistant titan alloys in aircraft engine [2]

perature is deform on such value, which is specified by technical specifications during definite time interval.

Long-term strength is evaluated by results of testing, under which the samples are affected by action of constant strengths of various levels up to disruption at various temperatures.

It is typical, that in low-pressure chambers of the above-mentioned engines the heat-resistant titan alloys, such as BT3, BT9, BT8, are used, pertaining to the group of $\alpha$-alloys, which are used for low-pressure chambers [2]; and in high-pressure chambers the twophase heat-resistant $(\alpha+\beta)$-titan alloys, such as BT25y [3] heat-resistant alloy, are used, which have strength $\sigma_{\mathrm{B}}=1080 \mathrm{MPa}$ at $20 \operatorname{deg} \mathrm{C}$ and $\sigma_{\mathrm{B}}=784 \mathrm{MPa}$ at $550 \operatorname{deg} \mathrm{C}$, which exceed corresponding values of many single-phase heat-resistant alloys.

New engine designers pose the problem for increasing of both operating temperatures of parts and assemblies of future engines, and long-term strength of promising alloys.

The aim of this article is determination of longterm strength of welded joints realized by EBW of

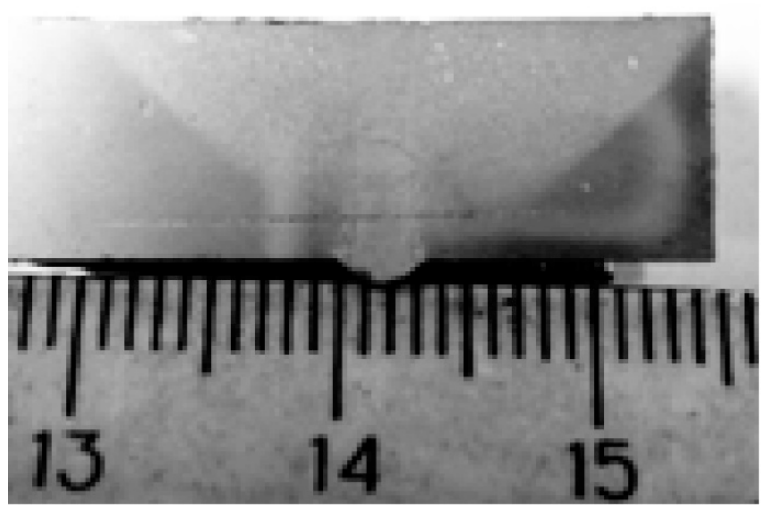

a) heat-resistant titan alloy of the following compositions (mass \%): Al-9\%: Sn-5\%; Nb-6\%; Zr-6,5\%; Mo-5,7\%; V-1\%; Si- $0,2 \%$.

\section{Results of investigation}

The EBW was carried out per one pass with УЛ-144 plant. The welding was performed by the following mode of operation: $U_{\text {acc }}=60 \mathrm{\kappa V}, I_{\text {eb }}=80 \mathrm{~mA}$, $v_{\text {weld }}=7 \mathrm{~mm} / \mathrm{s}$. Temperature checking during the EWB fulfillment was carried out by means of thermocouples attached to the seam root side (Fig. 2). Methodology used is in [4].

In Fig. 3 the macro-sections of welded joints of titan alloy realized by EBW with utilization of local beam thermal treatment $(a)$, as well as electron beam local thermal treatment and isothermal furnace treatment $(b)$ are shown.

Long-term strength tests of heat-resistant titan alloy samples of the following compositions: Al-9\%: Sn-5\%; Nb-6\%; Zr-6,5\%; Mo-5,7\%; V-1\%; Si-0,2\% (hereinafter called as Ti- $\alpha_{2}$ ), were carried out in the test laboratory of the E. Paton EWI (accreditation certificate No. 2H362 of January, 14, 2014).

Long-term strength test was carried according to GOST 10145-81 "Metals. Stress-rupture test method". Before the testing the samples of welded joint, realized

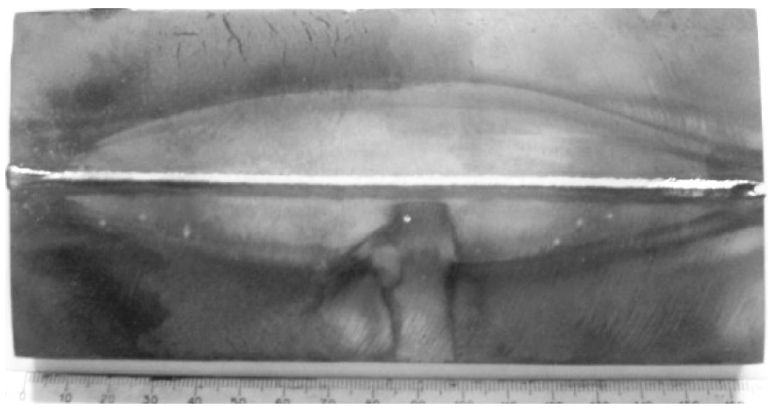

Fig. 2. Point of thermocouple installation for temperature measuring during EBLTT fulfillment

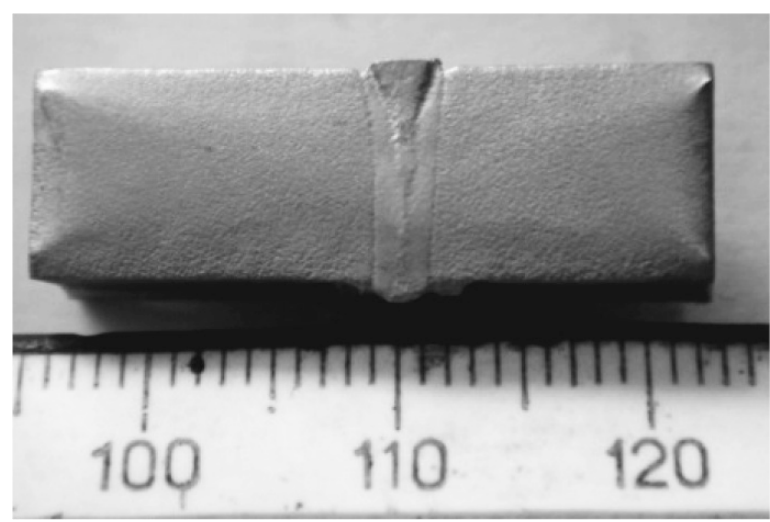

б)

Fig. 3. External view of macro-sections of titan alloy:

a) realized with utilization of beam local thermal treatment; $b$ ) with electron beam local thermal treatment and isothermal furnace treatment 


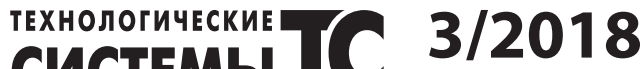

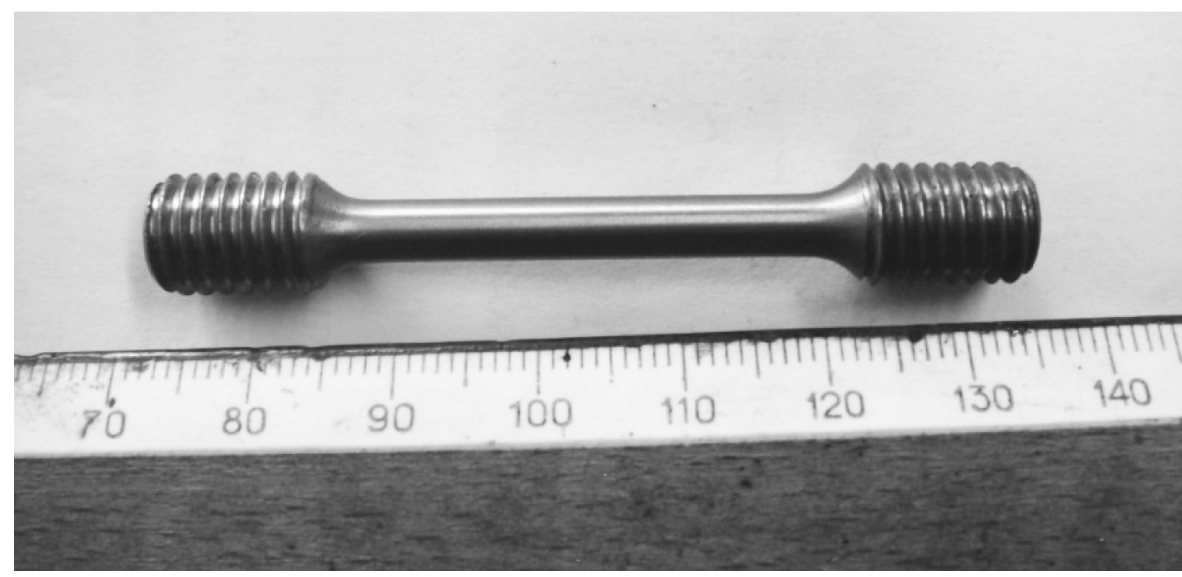

Fig. 4. General view of sample of Ti- $\alpha_{2}$ heat-resistant alloy welded joint realized by EBW intended for long-term strength test
By results of test the diagram of long-term strength in logarithmical coordinates $\sigma_{\mathrm{MPa}} \times \tau_{\mathrm{hr}}$ was plotted [5].

Graphical characteristic obtained (see Fig. 5) gives the possibility to extrapolate the test results for more prolonged period. Nevertheless, such method permits to obtain approximate values only, because under more prolonged tests the structure changes are possible which may lead to the strength change with the result that deviation from proportional dependence may occur. Usually, the deviation of by EBW method, and basic metal were subjected to isothermal annealing in the following manner: heating 1000 deg $\mathrm{C}$, exposure $1 \mathrm{hr}$, cooling with furnace up to 600 deg $\mathrm{C}$, aging $6 \mathrm{hr}$, air cooling.

Long-term strength test. Long-term strength test was carried on cylinder samples dia $5 \mathrm{~mm}$ of investigated heat-resistant titan alloy $\mathrm{Ti}-\alpha_{2}$ welded joint realized by EBW and is presented in Fig. 4 .

The samples were tested on machines МП-3Г (GOST 1533-81). After visual inspection and metering the sample was installed into the claws of МП-3Г testing machine. Three thermocouples were attached to the sample for temperature checking. During the test the sample temperature was checked by three ТПП-2 thermocouples placed in three points along operation length of the sample. The samples were tested at temperature 600 deg C. During the test the temperature was maintained on constant level with accuracy \pm 2 deg $\mathrm{C}$ and was registered on КСП-4 device. After temperature equalization according to the thermocouples indications the prescribed load was applied to the sample. Time interval up to the break at assigned stress value is the main index for such kind of test. forecasted values of long-term strength from real ones is within 5-25\%.

According to the diagram data, presented in Fig. 5, the long-term strength of welded joint slightly higher than long-term strength of basic metal, which may be connected with refining (refinement) of seam metal in melting zone. In the Table 1 the data of mechanical tests of welded joints and basic metal for long-term strength are shown.

Long-term strength limit of welded joint materials is $\approx 280 \mathrm{MPa}$, whereas long-term strength limit value of basic metal at the same temperature $600 \mathrm{deg} \mathrm{C}$ is some lower $(\approx 260 \mathrm{M \Pi a})$.

Scattering of long-term strength limit values for basic metal is $300-260 \mathrm{MPa}$ at the time to breakage of 95-38 hours, whereas such values for welded joint are 320-280 MPa and 80-49 hours, which is evidence of more high quality of welded joint seam metal, at least in the range of deformation duration of 80-49 hours (Fig. 6).

Metallographic investigations. Sample seam metal, cut out from welded joint realized by EBW without isothermal furnace treatment (see Fig. $7 a, b$, $c)$, presents a small-laminar $\alpha+\beta$ structure with dis-

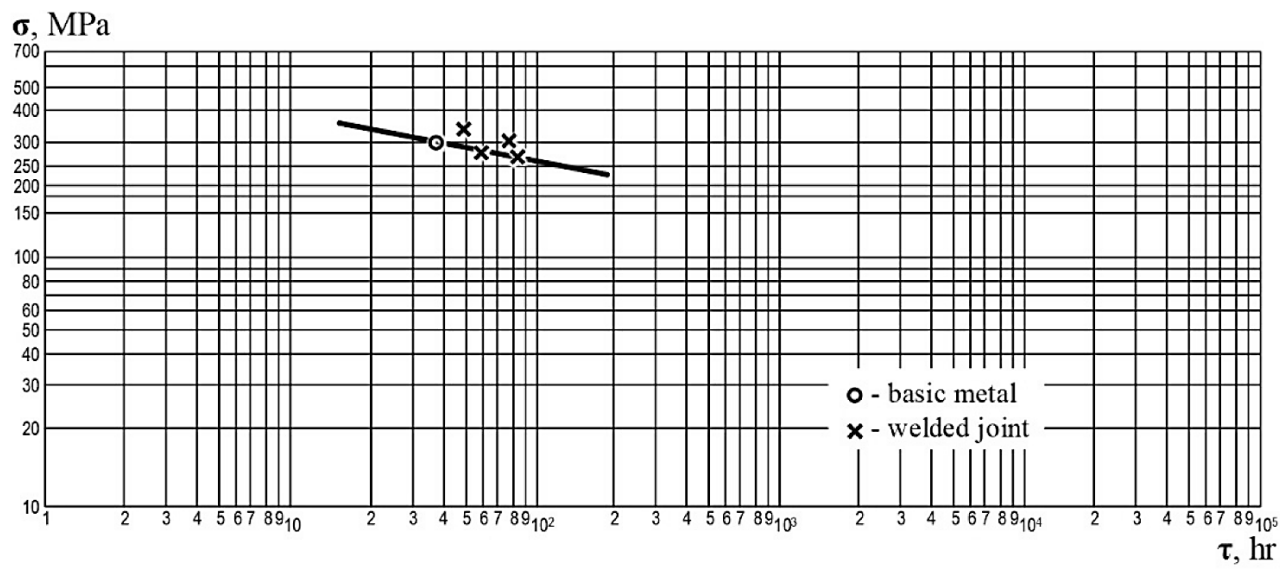

Fig. 5. Diagram of long-term strength of samples of basic metal and heat-resistant titan alloy Ti- $\alpha_{2}$ welded joint realized by EBW 
Results of welded joints and basic metal long-term strength tests at the temperature $600 \mathrm{deg} C$ after thermal treatment

\begin{tabular}{|c|c|c|c|c|}
\hline Sample name & $\begin{array}{c}\text { Long-term strength } \\
\text { limit } \sigma, \mathrm{MPa}\end{array}$ & $\begin{array}{c}\text { Time to breakage } \\
\tau, \mathrm{hr}\end{array}$ & $\begin{array}{c}\text { Specific elongation } \\
\delta, \%\end{array}$ & $\begin{array}{c}\text { Specific contraction } \\
\psi, \%\end{array}$ \\
\hline \multirow{4}{*}{ Basic metal } & 300 & $38^{00}$ & 36.1 & 44.7 \\
\hline & 300 & $47^{00}$ & 22.9 & 20.4 \\
\hline & 280 & $74^{00}$ & 24.7 & 31.0 \\
\hline & 260 & $95^{00}$ & 23.1 & 24.0 \\
\hline \multirow{4}{*}{ Welded joint } & 320 & $49^{00}$ & 14.5 & 35.7 \\
\hline & 300 & $74^{30}$ & 13.9 & 33.0 \\
\hline & 280 & $58^{20}$ & 13.3 & 43.9 \\
\hline & 280 & $80^{00}$ & 17.6 & 47.9 \\
\hline
\end{tabular}

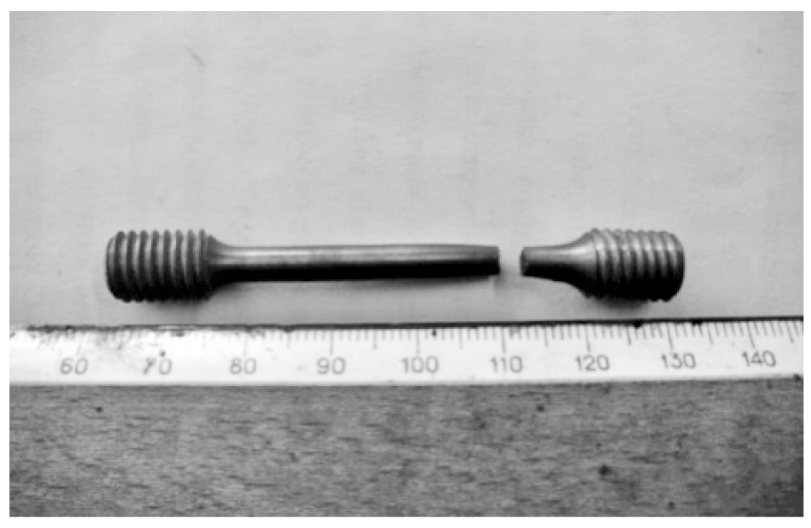

a)

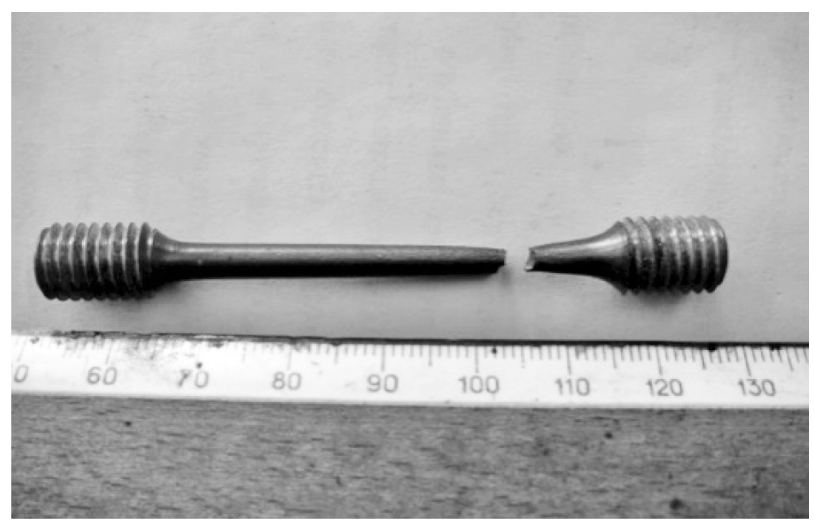

b)

Fig. 6. Test results:

$a$ - external view of basic metal sample after long-term strength test, subjected to isothermal furnace treatment $(T=600$ deg $\mathrm{C}$, $\left.\sigma=300 \mathrm{MPa}, \tau=38^{00} \mathrm{hr}, \delta=36.1 \%, \psi=44.7 \%\right) ; b$ - external view of welded joint sample subjected to isothermal furnace treatment after long-term strength test $\left(T=600 \operatorname{deg} \mathrm{C}, \sigma=280 \mathrm{MPa}, \tau=58^{20} \mathrm{hr}, \delta=13.3 \%, \psi=43.9 \%\right)$

charging of dark etching phase, situated on boundaries of casted crystallites. Analysis shows that after EBW the noticeable zonal inhomogeneity of metallographic structure is observed in the seam metal which negatively affect on mechanical characteristics of welded joint in whole.
Thus, the density of dark etching phase distribution along the seam height is change: it maximum is in the seam root (see Fig. $7 c$ ). It is necessary to note also, that in the seam root it was revealed more coarse-laminar structure (see Fig. 7c) in comparison with upper and central parts (see Fig. $7 a, b$ ).

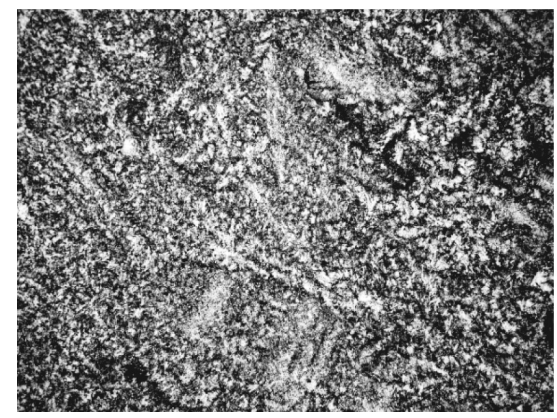

a)

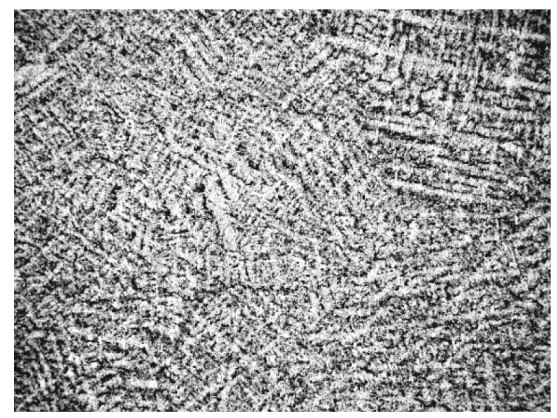

b)

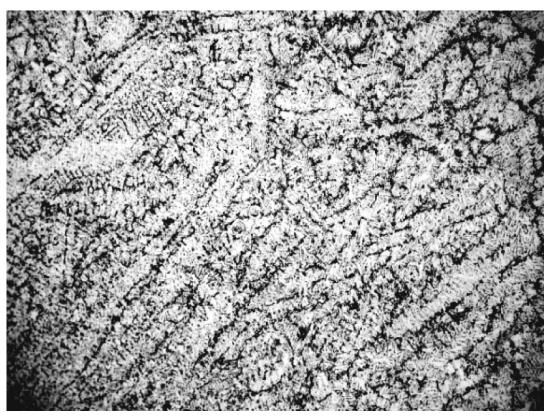

c)

Fig. 7. Microstructure of seam metal for welded joint realized by EBW with fulfillment of local electron-beam thermal treatment: $a$ - seam upper part; $b$ - central part; $c$ - root part; $a, b, c-\times 200$ 


\section{TЕхнологическив:TC 3/2018}

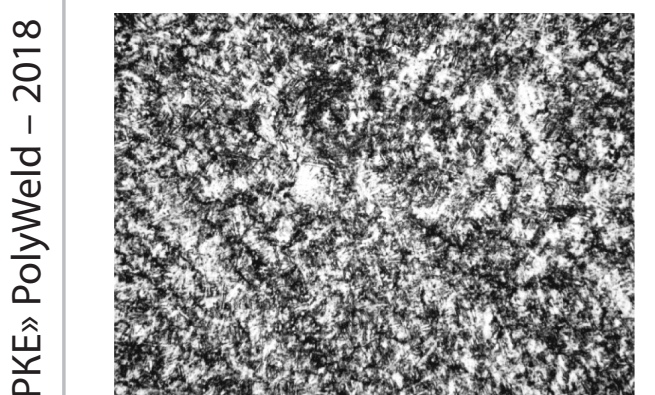

a)

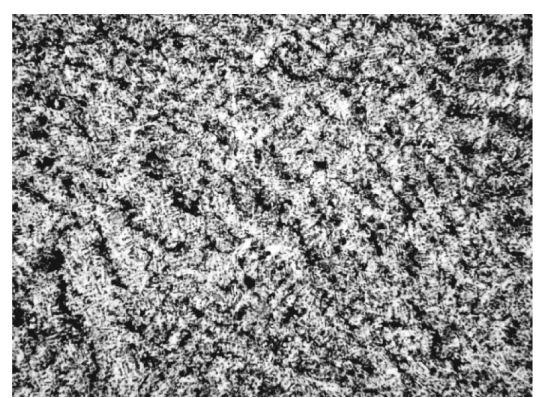

b)

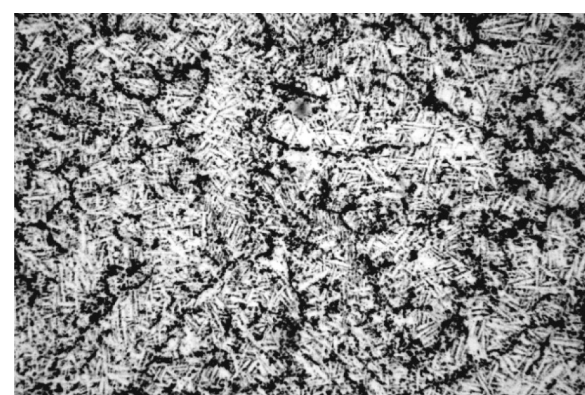

c)

Fig. 8. Microstructure of welded joint seam metal after long-term strength test without thermal treatment fulfillment: $a$ - seam upper part; $b$ - seam central part; $c$ - root part; $a, b, c-\times 500$

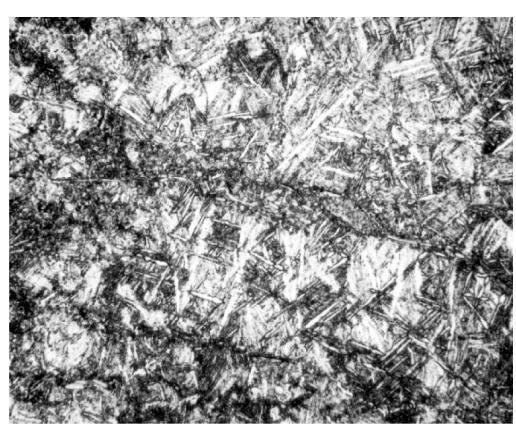

a)

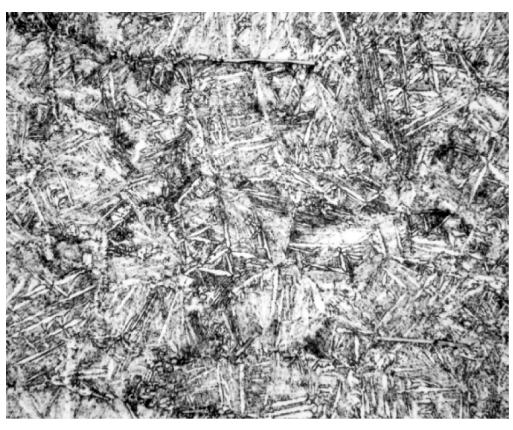

b)

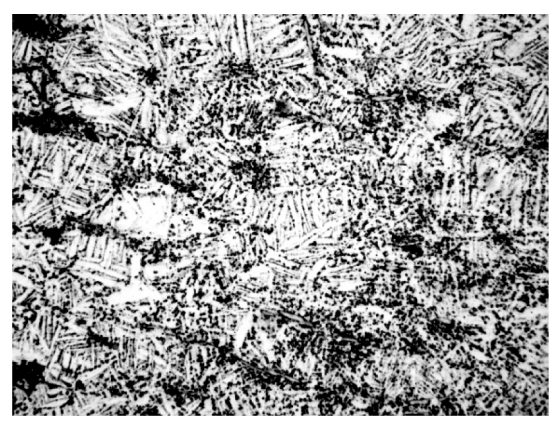

c)

Fig. 9. Microstructure of welded joint CGA of TAZ after long-term strength test without thermal treatment fulfillment:

$a$ - upper part; $b$ - central part; $c$ - root part; $a, b, c-\times 500$

In the area of coarse grain of thermal affection zone (TAZ) in upper and central parts of welded joint (see Fig. $8 a, b, c)$ the coarse-laminar $\alpha+\beta$ structure is observed.

Structure of coarse grain areas of TAZ is quite different and consists both from plates of $\alpha+\beta$ phases, and areas of equiaxed $\alpha+\beta$ structure (see Fig. $8 c$ ).

Microstructure of coarse grain area (CGA) of TAZ of welded joint metal (see Fig. 9) presents equiaxed $\alpha+\beta$ structure.

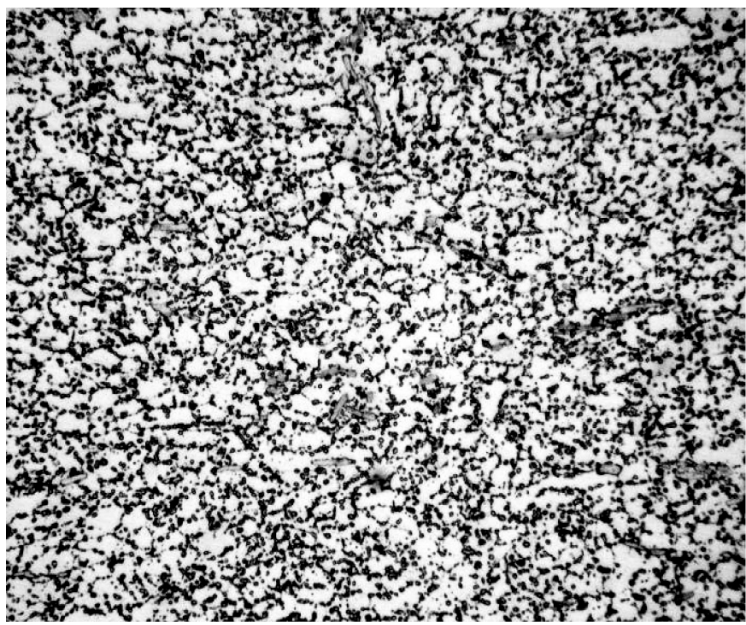

Fig. 10. Microstructure of basic metal of welded joint after long-term strength test without thermal treatment fulfillment $\times 500$
Microstructure of basic metal (see Fig. 10) presents granular $\alpha+\beta$ structure.

Microstructure of sample seam after long-term strength test after thermal treatment fulfillment (see Fig. $11 a, b, c)$ presents laminar basket type structure consisting of $\alpha+\beta$ phases. Structure of seam metal, as in the sample without thermal treatment (TT), changes considerably from seam root towards the strengthening: in seam root more coarse-laminar structure is observed (see Fig. 11c) in comparison with upper and central parts (see Fig.11a, $b$ ).

In coarse grain area of thermal affection zone more coarse-laminar $\alpha+\beta$ structure is observed in comparison with similar areas of seam (see Fig. 12a, $b, c$ ). Structure change in coarse grain area of TAZ is less revealed in comparison with seam metal structure.

Microstructure of basic metal (Fig. 13) presents equiaxed $\alpha+\beta$ structure which is identical to the microstructure of basic metal without thermal treatment.

Metallographic investigations after tests for long-term strength. In result of long-term strength tests the granular structure of basic metal enlarges considerably (see Fig. 14): increases both grain size of the basic phase and value of brittle phase discharge. Evidence of its brittleness is presence of cracks in separate discharges (see Fig. 14).

Granular $\alpha+\beta$ structure of seam metal after deformation becomes considerably finer in comparison with structure of sample obtained by electron beam welding and local thermal treatment. Specific peculiarity of the seam 


\section{3/2018 ТехнологическиеТС}

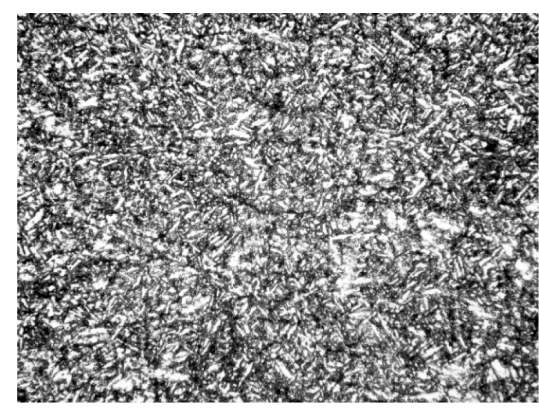

a)

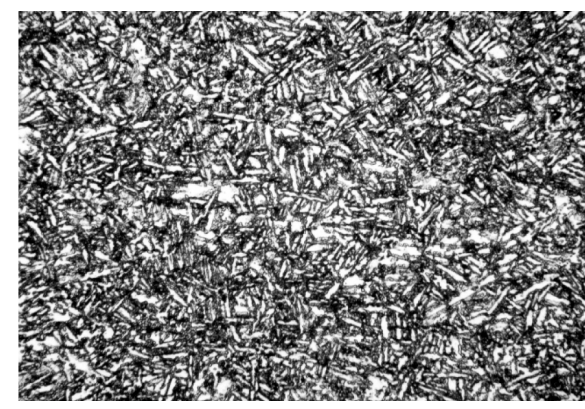

b)

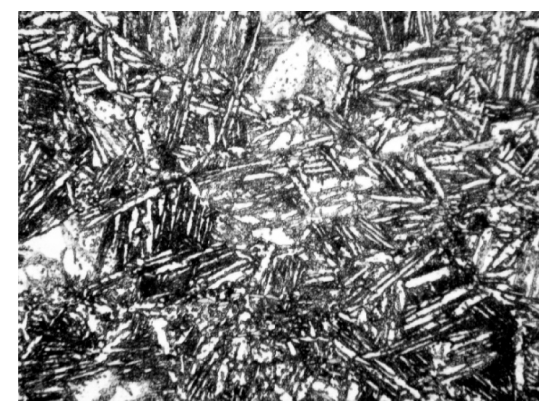

c)

Fig. 11. Microstructure of welded joint seam metal after long-term strength test with thermal treatment fulfillment: $a$ - seam upper part; $b$ - seam central part; $c$ - root part; $a, b, c-\times 500$

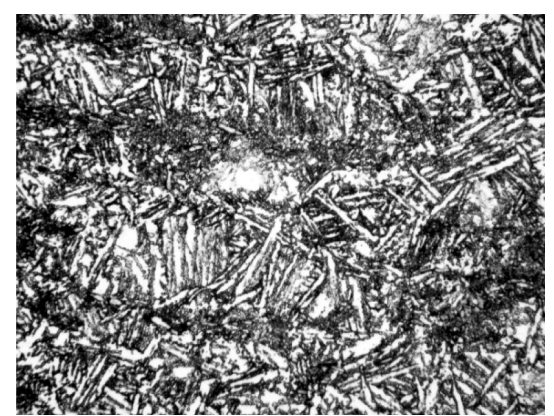

a)

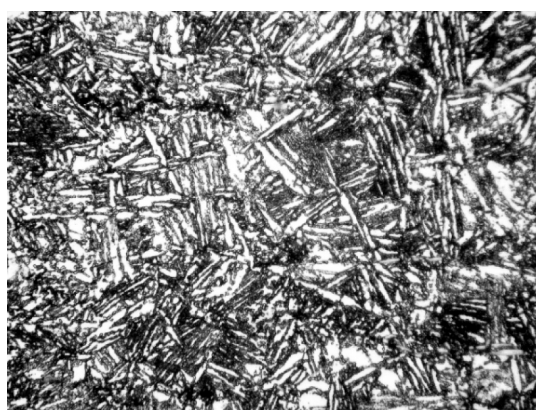

b)

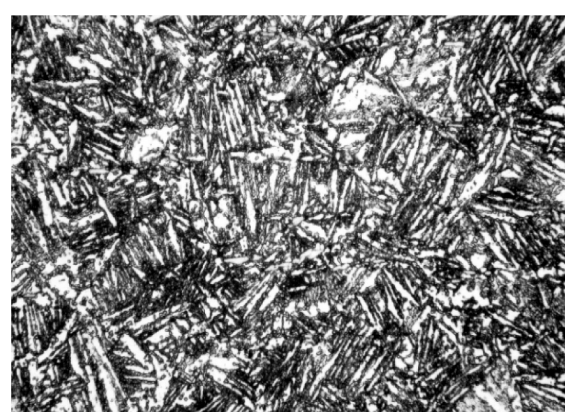

c)

Fig. 12. Microstructure of welded joint CGA of TAZ after long-term strength test with thermal treatment fulfillment: $a$ - upper part; $b$ - central part; $c$ - root part; $a, b, c-\times 500$

structure after long-term strength tests is considerable decrease of dark etching phase quantity (see. Fig. 15).

In CGA of TAZ after long-term deformation the microstructure enlarges considerably in comparison with structure after TT, besides, the structure undergoes changes in laminas orientation.

Whereas in the structure after TT the laminar basket type structure was predominate, then after longterm deformation the orientation of laminas at the

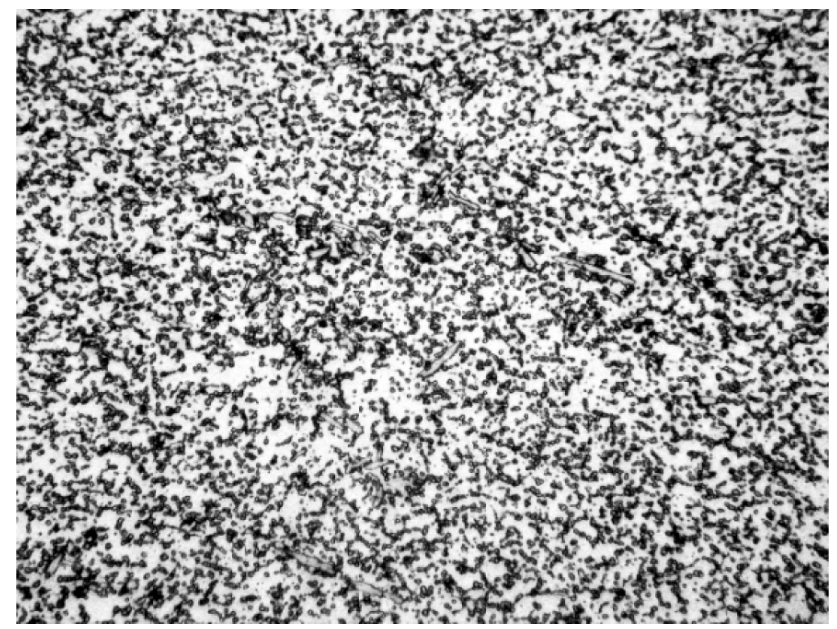

Fig. 13. Microstructure of basic metal of welded joint after long-term strength test with thermal treatment fulfillment, $\times 500$ angle of $60^{\circ}$ was observed, which is typical for more homogeneous structure (see Fig. 16).

In fine grain areas (FGA) of TAZ the microstructure is similar to the CGA of TAZ but is considerably finer (see Fig. 17).

In result of long-term strength test of heat-resistant titan alloy the microstructure of basic metal presents the grains elongated in direction of load application (see Fig. 18) with specific deformation texture.

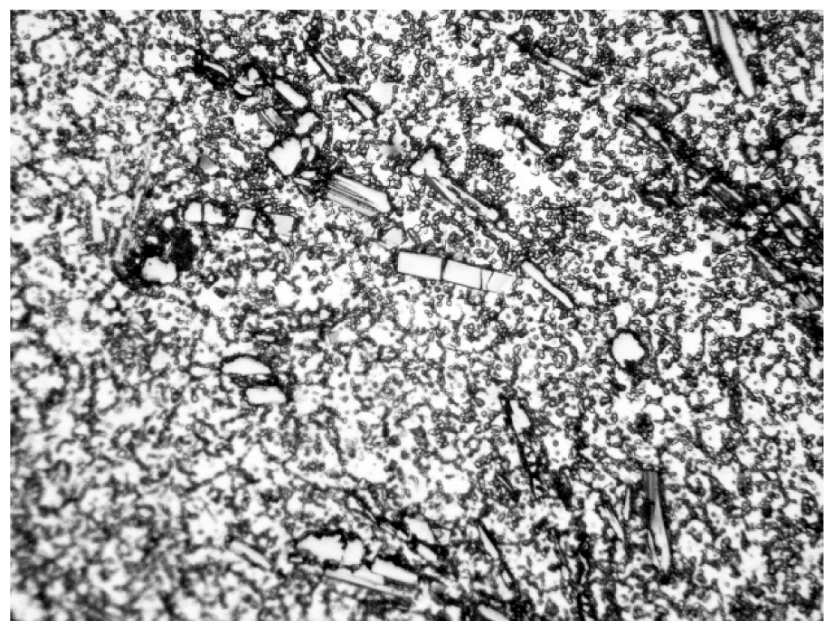

Fig. 14. Microstructure of basic metal after long-term strength tests fulfillment, $\times 500$ 


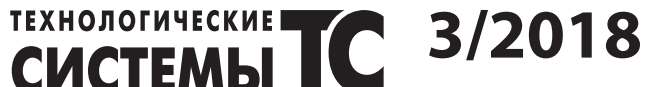

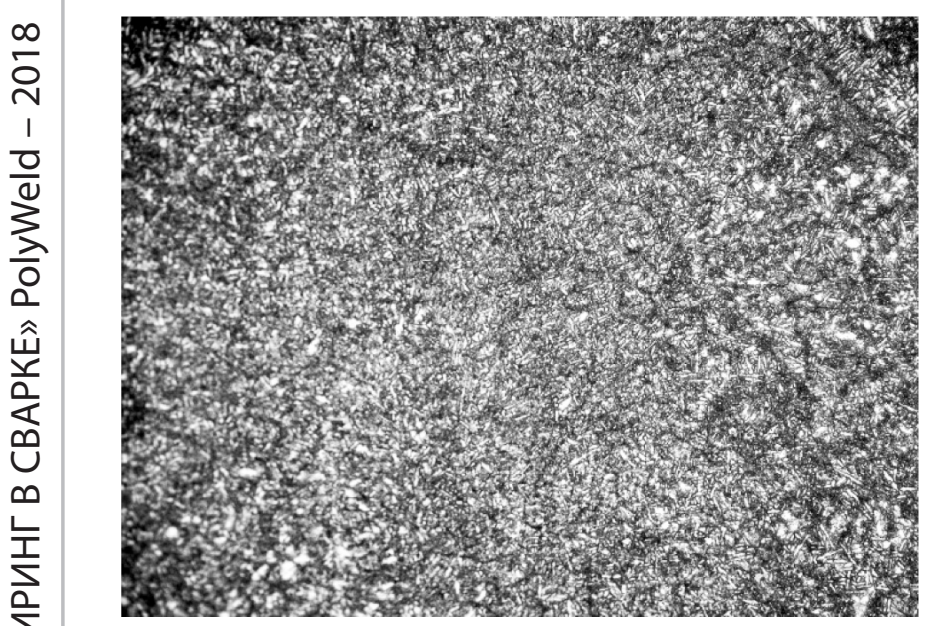

Fig. 15. Microstructure of seam metal after long-term strength tests fulfillment, $\times 200$

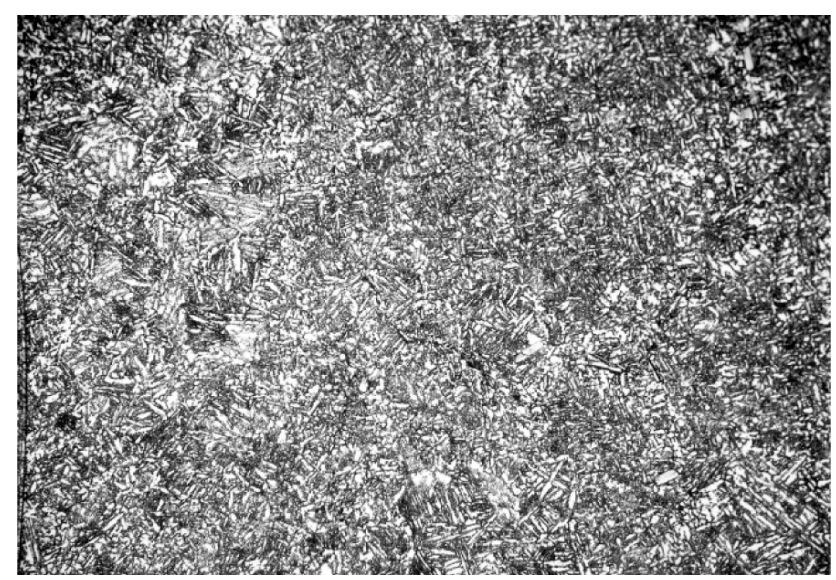

Fig. 17. Microstructure in FGA of TAZ in result of long-term strength test fulfillment, $\times 200$

Fractographic investigations. Fractographic investigations show that all samples after long-term strength test were dusrupted on basic metal. External view of disruption zone is in Fig. 20. Disruption surface after longterm strength test has weakly developed relief.

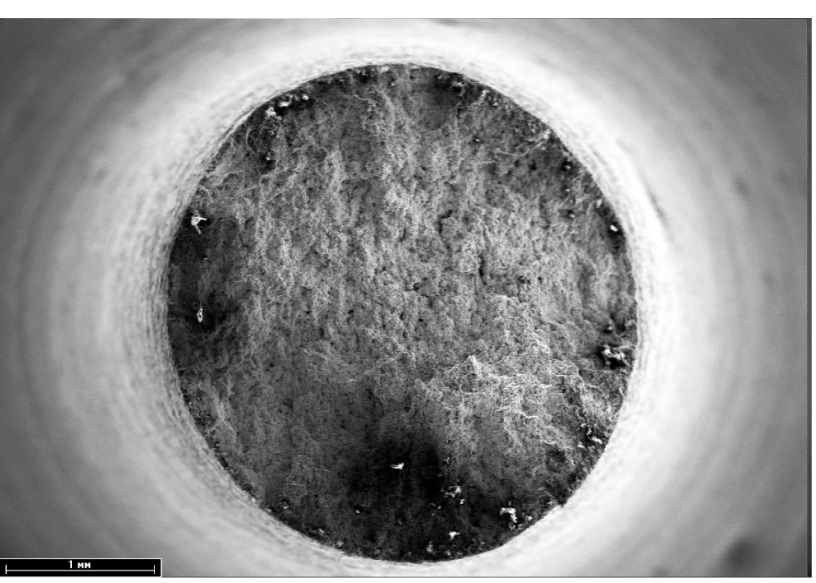

Fig. 20. External view of disruption surface of Ti- $\alpha_{2}$ heat-resistant titan alloy after long-term strength test

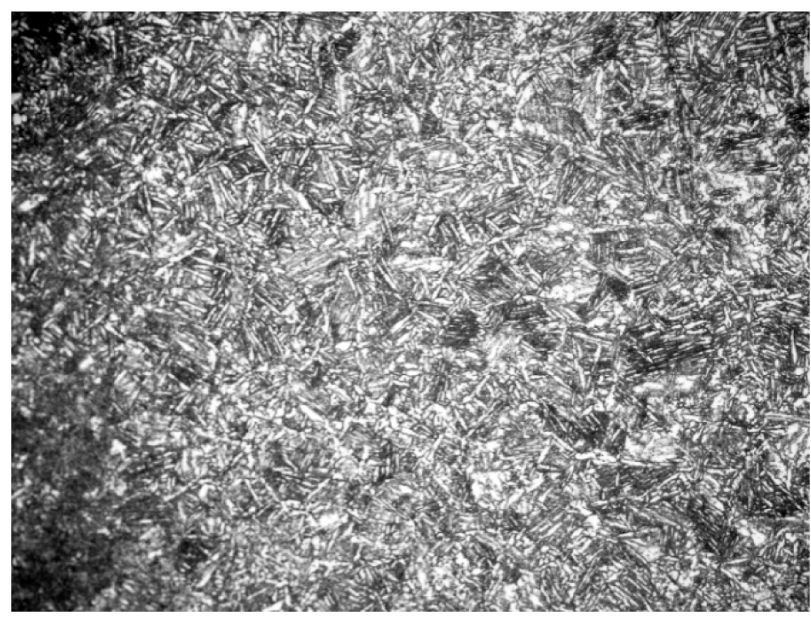

Fig. 16. Microstructure in CGA of TAZ after long-term strength tests fulfillment, $\times 200$

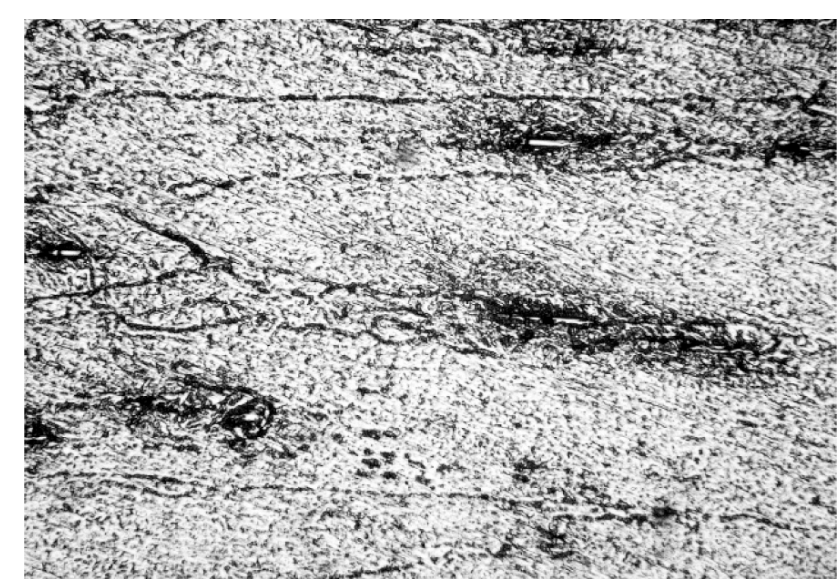

Fig. 18. Microstructure of heat-resistant titan alloy basic metal after long-term strength test

Disruption mechanism is of mixed type. On disruption surface the intermittent areas of cleavage facets are distinctly apparent, which are typical for brittle disruption and pit disruption and which are formed by mechanism of plastic flow and subsequent tearing (see. Fig. 21). Pits

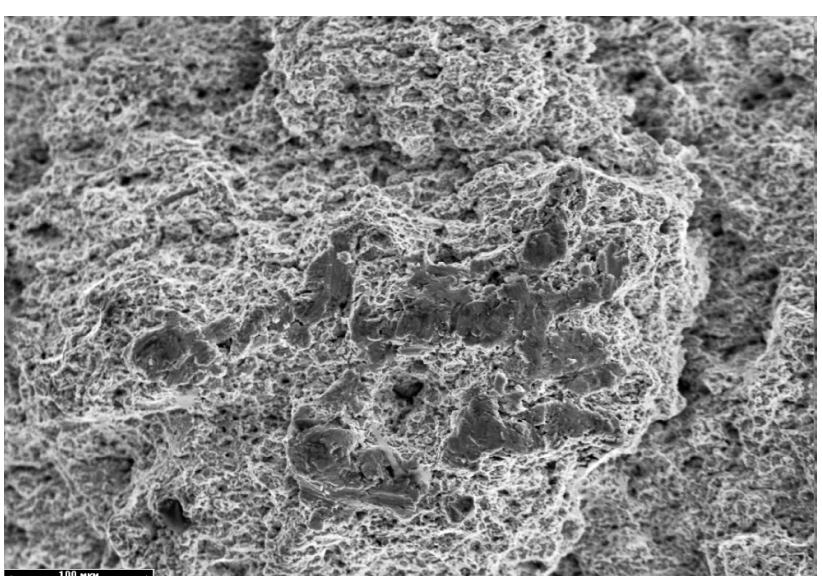

Fig. 21. Fractogram of Ti- $\alpha_{2}$ heat-resistant titan alloy disruption surface after long-term strength test 
are observed, which is evidence of plastic flow presence during long-term strength test.

Fine pit structure is observed onto facets, which is formed in the result of micro-plastic deformation. Disruption takes place on elements of coarse-laminar structure: cleavages during disruption are on packets of $\alpha$-laminas and on separate $\alpha$-laminas inside of initial $\beta$-grain.

Hardness measuring. Results of Vickers hardness analysis show that in the sample of welded joint without thermal treatment the stick-slip nature of hardness change is observed. Hardness of the seam metal is change within the limits from 4,400 $\mathrm{MPa}$ till 4,100 MPa. Then during transition into TAZ the considerable decrease of the hardness up to $3,500 \mathrm{MPa}$ takes place. In basic metal the increase of hardness till 3,800 MPa is observed. Such hardness change is connected with different conditions of seam metal crystallization in places of different remoteness from the hard metal, thermal treatment duration and heat removal, determining differences in structure of phase components and residual stresses.

Thermal treatment fulfillment permits to equalize these parameters and results in less stick-slip change of hardness in welded joint seam. At that, the seam metal hardness achievable is slightly higher in comparison with basic metal hardness. It points out the positive effect of furnace treatment process fulfillment, because under long-term deformation in contact zone of materials with different strengthening degree the crystal defects are developed usually, which results in disruption.

\section{Conclusions}

1. Long-term strength tests of heat-resistant Ti- $\alpha_{2}$ titan alloy samples of the following composition: Al9\%: Sn-5\%; Nb-6\%; Zr-6,5\%; Mo-5,7\%; V-1\%; Si-0,2\%, demonstrate that at the temperature $T=600 \mathrm{deg}$ C the long-term strength of welded joint is some higher than the basic metal strength, which may be connected with refining (purification) of seam metal in molten zone.

2. Welded seam of Ti- $\alpha_{2}$ alloy, obtained by EBW in regime $U_{\text {acc }}=60 \mathrm{kV}, I i=80 \mathrm{~mA}, v_{\text {weld }}=7 \mathrm{~mm} / \mathrm{s}$, characterized by significant inhomogeneity in granular $\alpha+\beta$ structure in upper, central and root areas of welded seam. This inhomogeneity results in considerable changes of material hardness in these areas.

3. Furnace thermal treatment (heating $T=1,000 \mathrm{deg} C$, storing 1 hour, cooling with furnace up to $\mathrm{T}=600 \mathrm{deg} \mathrm{C}$, aging $\tau=6$ hours, air storage) immediately after EBW permits to obtain the increased extent of homogenization of metallographic structure in different areas of welded seam and basic material.

4. During dusrupting of welded joint of heat-resistant Ti- $\alpha_{2}$ titan alloy samples by deforming at the temperature $T=600 \mathrm{deg} \mathrm{C}$ in duration ranges 80 - 49 hours the long-term strength limit of welded joint is higher of the same parameter of basic material on average of $6.7 \%$, which is witness of high quality of the composition obtained

\section{Nomenclature}

- temperature, deg C

- electrical voltage, $\mathrm{V}$

v - velocity, $\mathrm{m} \cdot \mathrm{s}-1$

\section{GreekSymbols}

$\sigma \quad$ - long-term strength limit, $\mathrm{MPa}$

$\tau \quad$ - time, s, hr

$\delta \quad-$ specific elongation, $\%$

$\psi \quad$ - specific contraction, \%

\section{Subscriptsand/Superscripts}

acc - accelerating

eb - electron beam

hr $\quad$ - time, hr

str - strength

weld - welding

\section{Abbreviations}

TAZ - thermal affection zone

EWI - E. O. Paton Electric Welding Institute of National Academy of Sciences of Ukraine

TT - thermal treatment

FGA - fine grain areas

EBLTT - electron-beam local thermal treatment

EBW - electron-beam welding

\section{References}

[1] Pisarenko G.S. About the question of long-term strength characteristics predictions under high temperatures. / Pisarenko G.S., Kovpak V.I. // Problem of strength.1976. - № 8. - pp 28-32.

[2] Kablov E.N. Intermetallics based on titanium and nickel for advanced engineering products Kablov E.N., Lukin V.I. // Automatic welding-2008. - No. 11 (667). pp. 76-82. - Bibliography : 16 publ. - poc. http://dspace. nbuv.gov.ua/bitstream/handle/123456789/100041/09Kablov.pdf?sequence $=1$

[3] Ilienko V.M., Shalin R.E. Titan allows for aircraft gasturbine engines // Titan (VILS) 1995. No.1-2. pg. 25.

[4] Vrzhizhevskiy E.L. Influence of local thermal treatment of titan alloys during EBW with siliconized strengthening on mechanical properties of seam metal / Vrzhizhevskiy E.L., Sabocar V.K., Akhonin S.V., Petrichenko I.K. // Automatic welding. - 2012. - No.2. - pg. 21-24.

[5] Instruction for long-term strength test fulfillment. Odinch I.A. Head of strength laboratory, Corresponding Member of AC of USSR, Moscow, 1960. 


\author{
УДК 621.791
}

Вржижевский Э. Л. ${ }^{1}$, Таранова Т. Г. ${ }^{1}$, Ахонин С. В. ${ }^{1}$, Явдощина Е. Ф. ${ }^{1}$, Соломийчук Т. Г. ${ }^{1}$, Зворыкин К. О. ${ }^{2}$

${ }^{1}$ Институт электросварки имени Е. О. Патона НАН Украины. Украина, г. Киев

${ }^{2} \mathrm{AO}$ «Украинский научно-исследовательский институт авиационной технологии». Украина, г. Киев

\title{
ОСОБЕННОСТИ ДЛИТЕЛЬНОЙ ПРОЧНОСТИ СВАРНЫХ СОЕДИНЕНИЙ ЖАРОПРОЧНЫХ ТИТАНОВЫХ СПЛАВОВ ПОСЛЕ ЛОКАЛЬНОЙ ТЕРМИЧЕСКОЙ ОБРАБОТКИ ПРИ ЭЛС
}

Для разработки новых конкурентоспособных авиационных двигателей необходимо использовать новые легкие жаропрочные титановые сплавы. Это позволит решить проблему повыиения температуры в газотурбинном двигателе (камеры низкого и высокого давления). Специфика использования новейших сплавов требует от них высокой жаропрочности и высокой пластичности. Основными характеристиками жаропрочности являются длительная прочность и предел ползучести. В работе были проведены испытания на длительную прочность образцов жаропрочного титанового сплава следующего состава: \%(масс.): Al-9\%: Sn-5\%; Nb-6\%; Zr-6,5\%; Mo-5,7\%; V-1\%; Si-0,2\%, в испытательной лаборатории ИЭС им. Е. О. Патона (аттестат аккредитации №2Н362 от 14 января 2014 г.). Поведены металлографические и фрактографические исследования сварных соединений образцов и основного металла, исследуемого жаропрочного титанового сплава. Примененный способ әлектронно-лучевой сварки с локальной термообработкой показал полное отсутствие каких-либо дефектов в сварных соединениях. [dx.doi.org/10.29010/084.9]

Ключевые слова: жаропрочные титановые сплавы; длительная прочность; электронно-лучевая сварка; структура; микротвердость.

\section{Литература}

[1] Писаренко Г.С. К вопросу о прогнозировании характеристик длительной прочности в условиях высоких температур / Г. С. Писаренко, В. И. Ковпак // Проблемы прочности. 1976. - № 8. - С. 28-32.

[2] Каблов Е. Н. Интерметаллиды на основе титана и никеля для изделий новой техники / Е. Н. Каблов, В. И. Лукин // Автоматическая сварка. - 2008. - № 11 (667). - С. 76-82. - Бібліогр.: 16 назв. - poc. http://dspace.nbuv.gov.ua/ bitstream/handle/123456789/100041/09-Kablov.pdf?sequence=1

[3] Ильенко В. М., Шалин Р. Е. Титановые сплавы для авиационных газотурбинных двигателей //Титан (ВИЛС). 1995. № 1-2. С. 25.

[4] Вржижевский Э. Л. Влияние локальной термической обработки при ЭЛС титановых сплавов с силицидным упрочнением на механические свойства металла швов / Э. Л. Вржижевский, В. К. Сабокарь, С. В. Ахонин, И. К. Петриченко // Автоматическая сварка. - 2012. - № 2. - С. 21-24.

[5] Инструкция по проведению испытаний на длительную прочность. Зав. лаб. прочности, член-корр. АН СССР Одинч И. А., Москва 1960 г. 